\title{
Clinical Mastitis in Norwegian Herds After a Combined Selective Dry-Cow Therapy and Teat-Dipping Trial
}

\author{
A. C. Whist, ${ }^{*}{ }^{1}$ O. Østerås, ${ }^{*} \dagger$ and L. Sølverød†‡ \\ *Norwegian School of Veterinary Science, Department of Production Animal Clinical Sciences, PO Box 8146, N-0033 Oslo, Norway \\ †TINE Norwegian Dairies, Department of Norwegian Cattle Health Services, PO Box 58, N-1431 Ås, Norway \\ ¥TINE Norwegian Dairies Mastitis Laboratory, Fannestrandvegen 55, 6415 Molde, Norway
}

\section{ABSTRACT}

The objective of this study was to see if introduction of a 2-yr combined selective dry-cow therapy and teatdipping trial would reduce clinical mastitis (CM) events in 164 Norwegian dairy herds. Three different penicillin or penicillin/dihydrostreptomycin-based dry-cow treatments, and 3 different teat-dipping regimens (negative control, iodine teat dip, or an external teat sealant) were independently and randomly allocated to each herd. Complete lactations both before and during the trial were investigated. Altogether, 1,005 CM cases were recorded in the lactations before the trial and 924 cases were recorded during the trial. Bacteriological milk samples were available from 784 of the 924 CM cases during the trial. Among these, Staphylococcus aureus were isolated from $47.4 \%$, Streptococcus dysgalactiae from $22.5 \%$, Escherichia coli from $10.7 \%$, and coagulasenegative staphylococci from $6.3 \%$. In addition, $12.5 \%$ cases were bacteriological negative, and the remainder of the CM cases were caused by other microbes. The different models were analyzed using Cox regression analysis with PROC PHREG and a positive stable frailty model in the SAS macro. Separate models were made for cows housed in tie-stalls and free-stalls. Parity had a significant impact on the CM risk in both type of stalls. Older cows (parity $>3$ ) had the highest hazard ratio of contracting $\mathrm{CM}$ in tie-stalls (1.68) and freestalls (2.18) compared with parity 1 . The CM risk decreased significantly (13\%) in tie-stalls and by $18 \%$ in free-stalls. In tie-stalls, iodine-dipped cows had a significantly lower chance (21\%) of getting CM compared with the negative control and the use of external teat sealant. The same trend was seen in free-stalls; however, the differences were not significant. Compared with $\mathrm{CM}$ before the trial, the reduction of $\mathrm{CM}$ was $15 \%$ during the trial.

Key words: clinical mastitis, selective dry-cow therapy, teat dipping, external teat sealant

Received May 16, 2006

Accepted July 7, 2006.

${ }^{1}$ Corresponding author: anne.c.whist@veths.no

\section{INTRODUCTION}

Clinical mastitis (CM) is defined as udder inflammation characterized by visible abnormalities in the milk or the udder, or both. Severity of clinical cases can be described as mild, moderate, or severe (International Dairy Federation, 1999). The risk factors for udder infection can be individual cow factors or environmental factors. The former includes factors such as milkingout properties, acquired and innate immune resistance, teat anatomy, and physiological factors. The environmental factors are either uncontrolled, such as air temperature, season, rainfall, and so on, or factors that are partly under control such as hygiene, type of milking, nutrition, and type and virulence of the microorganisms (Oliver et al., 1956; Østerås and Lund, 1988a,b; Barkema et al., 1999a,b).

Routine teat dipping and blanket dry-cow therapy are regarded as the 2 most important components of a mastitis control system (Kingwill et al., 1970). The application of a control system has shown reduction of both clinical and subclinical mastitis, largely because of a reduction in the number of staphylococcal and streptococcal infections. Concerns have been raised that blanket dry-cow therapy will result in an overuse of antibiotics. Some countries, including Norway, have therefore adopted selective use of dry-cow therapy (Bratlie, 1972; Browning et al., 1990, 1994; Østerås et al., 1999). The method chosen in a selective dry-cow therapy program must satisfy 2 demands: first, it must be simple and inexpensive enough to be used by the dairyman, and, second, it must be sensitive enough to maximize treatment of infected quarters (or cows) while minimizing treatment of healthy quarters (or cows). Postmilking teat dipping has generally not been recommended in Norway; a national survey revealed that only $12 \%$ of Norwegian farmers used postmilking teat dipping regularly (Østerås and Sølverød, 2005).

An alternative to dry-cow therapy is an external teat sealant. An external teat seal consists of a physical barrier covering the teat canal. Closing of the teat canal could reduce the amount of pathogens entering the udder at the beginning of the dry period or before calving 
and thus reduce the incidence of $\mathrm{CM}$ during the next lactation.

The objective of this paper was to investigate if a combined selective dry-cow therapy and teat-dipping trial could reduce the CM risk in Norwegian herds.

\section{MATERIALS AND METHODS}

\section{Selection and Randomization of the Herds Participating in the Trial}

The same basic data material was used in this study as in the study described by Whist et al. (2006) and a summary is given here. Our study population originally included 215 commercial Norwegian dairy herds.

The legal criteria for inclusion for herds were as follows: 1) herds had to be members of the Norwegian Dairy Herd Recording System (NDHRS), 2) the farmer was willing to use the dry-cow therapy and teat-dipping regimen he/she was given according to a random selection process, 3) the farmer had to deliver milk to TINE BA (The Norwegian Dairies) during the study period, 4) the farmer had cow (composite) milk somatic cell count (CMSCC) test-days taken monthly during the study period, and 5) the farmer was encouraged to implement the Nordic recommendations concerning milking routine described by Alfnes and Østerås (1992).

The legal criteria for exclusion were as follows: 1 ) the farmer withdrew from the study because he/she did not follow the protocol, 2) the farmer withdrew from the study if the local veterinarian suspected that the protocol was not being followed, or if $50 \%$ or more of the quarter milk samples were forgotten, or 3) herds were withdrawn if co-ownerships were dissolved during the study period.

Randomization of the combined selective dry-cow therapy and teat-dipping trial was conducted as a computerized systematic random assignment. The trial lasted for $2 \mathrm{yr}$, from October 2002 until June 2005, and was based on the Norwegian selective dry-cow therapy regimen described by Østerås and Sølverød (2005) and a teat-dipping protocol. Complete lactations were followed before and during the trial to measure an increase or a decrease of CM due to the implementation of the trial. Lactations that had started before the trial and continued into it were therefore excluded. A complete lactation was defined from $15 \mathrm{~d}$ before a calving to $15 \mathrm{~d}$ before the next calving or to the culling date. Lactations that started during the trial and continued after the end of the trial were censored at the end of the trial.

Annual quarter milk samples were taken for bacteriological examination at the beginning of the trial, and again after 1 and $2 \mathrm{yr}$. The 2 last annual samples were taken as close to $365 \mathrm{~d}$ as possible from the previous herd sampling to avoid any seasonal effect as described by Østerås et al. (2006). Local veterinarians collected the first annual samples when they taught the farmers the aseptic milk sampling technique. The farmers then collected the 2 last annual samples. Bacteriological milk samples, dry-cow treatment, teat dipping, and measurement of different herd parameters started at the first annual sample.

All CM cases were recorded on a Norwegian Cow Health Card by the veterinarians or the farmer and reported to the NDHRS. This system has been operating nationally since 1975 (Solbu, 1983), and all disease treatments, with special health code and date of event, are reported to the central database. Recording of culling was also reported to the database. No drycow treatments were recommended for cows with a geometric mean of the last 3 CMSCC test-days $>600,000$ to 700,000 cells $/ \mathrm{mL}$ and a positive Staph. aureus or Strep. dysgalactiae isolate before drying-off. These cows were instead assessed for culling after calving. In this trial, culling date, calving date, and parity from the database were used.

Additionally, all veterinarians and farmers involved in the trial were encouraged to take quarter milk samples from all 4 quarters before treating any CM. These samples were analyzed at the TINE Mastitis Laboratory (Molde, Norway) and the data were transferred to NDHRS, as has been done routinely since 2000 .

\section{Selection and Randomization of Control Herds}

The control herds consisted of herds from the same geographical areas as the herds participating in the trial, and they were originally randomized into the trial with a dry-cow therapy and a teat-dipping regimen. These herds were not included in the trial due to the exclusion criteria mentioned or they were not asked to participate due to excessive number of herds already participating in that specific area. No implementation of selective dry-cow therapy and teat dipping was conducted in these herds. Because dry-cow therapy is seldom used in Norway (with only 1,458 recorded treatments during 2005), we expected only a few cows to be treated in these herds. As for teat dipping, only $12 \%$ of Norwegian farmers apply teat dipping routinely (Østerås and Sølverød, 2005), meaning that probably about $12 \%$ of the control herds were using any teat dip. The only inclusion criteria for these herds were: 1) herds had to be members of the NDHRS, 2) the farmer were advised to implement the Nordic recommendations concerning milking routine described by Alfnes and Østerås (1992).

We used the mean of the first annual sample days for the participating herds in the same area as starting 
day for the control herds. The mean of the last annual sample days was used as the day when the herds were released from the study.

\section{Selective Dry-Cow Therapy and Teat-Dipping Protocol}

Østerås and Sandvik (1991) conducted a similar study on dry-cow therapy in which a negative control group was included. They used a dry-cow therapy formula similar to Juvanesta (Boehringer Ingelheim Vetmedica AS, Asker, Norway; 300,000 IU of benzyl penicillin and $300 \mathrm{mg}$ of dihydrostreptomycin), which was used as a positive control in our trial, and justifies the lack of a negative control (Dohoo et al., 2003). Because Norway has neither formulas officially available nor approved for dry-cow therapy, both long- and shortacting formulas were used in the trial to examine differences between them. Additionally, most intramammary therapies in Norway include dihydrostreptomycin as well as benzyl penicillin. Thus, it is of interest to investigate if dihydrostreptomycin could be removed without any detrimental effect of therapy cure. The dry-cow therapies were as follows: 1) Juvanesta, a short-acting antibiotic with $300 \mathrm{mg}$ of penethamate hydriodide bencyl penicillin (300,000 IU of benzylpenicillin) and 300 $\mathrm{mg}$ of dihydrostreptomycin sulfate. If 1 or 2 quarters were infected with Staph. aureus or Strep. dysgalactiae, only these quarters were treated; if 3 or 4 quarters had infection, all 4 were treated. The treatment was repeated 4 times at 24-h intervals; 2) Siccalactin (Boehringer Ingelheim Vetmedica AS), a long-acting antibiotic consisting of $0.17 \mathrm{~g}$ of penicillinbenzatin $(200,000$ IU) and $0.4 \mathrm{~g}$ of dihydrostreptomycin sulfate. All 4 quarters were treated once, independent of the number of infected quarters; and 3) Mastipen (VetPharma AS, Snarøya, Norway), a short-acting antibiotic consisting of $300 \mathrm{mg}$ of penicillin (300,000 IU of bencyl penicillin procaine). If 1 or 2 quarters were infected with Staph. aureus or Strep. dysgalactiae, only these quarters were treated; if 3 or 4 quarters had infection, all 4 were treated. The treatment was repeated 4 times at 24$\mathrm{h}$ intervals.

The teat-dipping groups were group $\mathrm{A}$, the negative control group: No teat dipping was applied in the herd. If any teat dipping had been used previously, this practice was stopped before the herd entered the study period; group B: iodine teat-dipping using Proactive plus (DeLaval AS, Tumba, Sweden), a teat dip containing $0.15 \%(1,500 \mathrm{ppm})$ iodine (equivalent to 6 to $8 \mathrm{ppm}$ of free iodine). All teats in all lactating cows were dipped routinely after milking during the whole lactation. At drying-off, cows maintained in tie stalls were dipped 2 to $3 \mathrm{~d}$ postmilking and cows maintained in free-stalls were dipped up to the last day of milking. The whole teat was dipped in the iodine suspension and the remaining suspension left in the dip cup was emptied. The dip cup was washed daily after each milking; and group C: external teat sealant (DryFlex, DeLaval AS). All teats in all lactating cows were dipped with teat sealant at drying-off, $10 \mathrm{~d}$ before expected calving (including heifers), and again if the teat sealant had fallen off within $3 \mathrm{~d}$ of being applied. The teats were washed carefully and disinfected with a 70\% alcohol pad after the last milking. The teats were dried properly before application of the teat sealant. A DryFlex application cup was used for each cow, and the whole teat was dipped in the suspension.

\section{Bacteriological Examination of Quarter Milk Samples}

All quarter milk samples from all CM cases were submitted for bacteriological examination at TINE Norwegian Dairies Mastitis Laboratory, Molde, Norway. The samples were analyzed for bacterial growth on blood agar plates (blood agar base, Oxoid Ltd., Basingstoke, UK) mixed with $5 \%$ washed bovine erythrocytes. The examination of bacterial growth and diagnostics followed the official Norwegian procedure (National Veterinary Institute, 1993) and was in agreement with the recommendations of the International Dairy Federation (1981). The procedure and examination of bacterial growth were as described by Østerås et al. (2006).

\section{Statistical Analysis}

Participating Herds. The data were imported into SAS and all calculations were performed by using SAS Version 9.1 (SAS Institute, Inc., Cary, NC). The data from the participating herds in the trial were divided between tie-stalls and free-stalls and separate models were made for each stall type. The CM cases included severe, moderate, and mild cases (International Dairy Federation, 1999) and were reported to the NDHRS. The risk of CM for each cow was measured both in the complete lactation before the cow went into the trial, and during the trial. The time from $15 \mathrm{~d}$ before calving until the first $\mathrm{CM}$ event was used as the dependent variable in the models. If no $\mathrm{CM}$ case occurred during the lactation, a cow was censored at the time of her next calving, the last annual herd sample (the defined end of the trial) or at her culling date. The full models consisted of the independent fixed variables: parity (class 1, 2, 3 and $>3$ ), sine and cosine of calving day to evaluate any seasonal effect as described by Schukken et al. (1990) and Østerås et al. (2006), dry-cow therapy group (Juvanesta, Siccalactin, or Mastipen), teat-dip- 
ping group (A, B, or C), interaction between the lactation before or during the trial and the different drycow therapy groups as well as the interaction between lactation before or during the trial and the different teat-dipping groups. The independent fixed variables were excluded one by one from the full model with backward elimination procedure until all remaining variables had a $P$-value $\leq 0.10$. However, doing this, the interaction term stayed in the model as long as the corresponding dry-cow therapy or teat-dipping variable stayed in the model. A $P$-value $\leq 0.05$ was considered significant.

Separate models were also made for the different pathogen-specific CM caused by Staph. aureus, Strep. dysgalactiae, Escherichia coli, and CNS. This information was not available in the control herds and in the lactations before the trial and was therefore only conducted in the participating herds during the trial. The pathogen-specific CM was used as time-dependent variables and the same independent variables were used as described for the full model.

All the models were analyzed using Cox regression analysis (Cox, 1972) with PROC PHREG and the positive stable frailty model in the SAS macro (SAS Institute; Shu and Klein, 1999; Shu and Klein, 2005). This analysis is based on the concept of a hazard function $\gamma(t)$, where $\gamma(t)$ is the limiting probability for a cow to have her first mastitis at time $t$ (expressed in days), given that she was still unaffected prior to $t$. The hazard ratios (HR) for CM with 95\% confidence intervals (CI) were obtained for all covariates. The fit of the model was evaluated by plotting the deviance residuals against the covariates to see if the models fitted the data adequately (Allison, 2000). To check for proportional hazard assumption, the log of the negative log of survival was plotted against time with the most important independent variable as strata. These assessments showed no evident violations of the proportional hazard assumption, extreme deviance residuals, or patterns in the models. The final model assessment fit was evaluated by comparing the log likelihood for the full model with the log likelihood for the partial model. The significance of the frailty effect was assessed by $\mathrm{H}_{0}: \theta=1$. Frailty effect was judged significant when $P<0.05$.

Control Herds. For the control herds, housing information was missing. Therefore, a separate model was run to investigate the overall effect on $\mathrm{CM}$ during the whole trial. In this model, parity (classes $1,2,3$, and $>3$ ), season, lactation before and during the trial, control herd or participating herd in the trial and the interaction between lactation before/during and control herd and participating herd were used as independent variables. This model was made with Cox regression model as described for the model including trial herds, except for the inclusion of frailty effect.

\section{RESULTS}

\section{Description of the Participating Herds}

Of the 215 herds initially enrolled, 142 tie-stall and 22 free-stall herds remained in the study after $2 \mathrm{yr}$. Twelve farmers withdrew from the study because they did not manage to follow the protocol, or they suffered an accident or force majeure outside the project. Another 23 farmers withdrew because their local veterinarian suspected that the protocol was not being followed or because $50 \%$ or more of the milk samples were forgotten. Two farmers withdrew because their co-ownerships were dissolved during the study period, and 14 herds were lacking information about stall types or had a stall type that could not be characterized as a tiestall or a free-stall.

For the 164 participating herds, the herd characteristics during the trial were as follows; the mean herd size was 25 cows $(\mathrm{SD}=9.2)$, the mean annual milk yield was $6,627 \mathrm{~kg}(\mathrm{SD}=674)$, and the mean bulk milk SCC was 110,000 cells $/ \mathrm{mL}(\mathrm{SD}=31,000)$. The distribution of parities was as follows: 39.7 and $38.2 \%$ were first-parity cows before and during the trial, respectively, 26.3 and $26.6 \%$ were second-parity cows before and during the trial, 16.6 and $16.5 \%$ were third-parity cows before and during the trial, and 17.4 and $18.8 \%$ were fourth-parity or higher cows before and during the trial, respectively. The lactation lengths, presented as quartiles, before (during) the trial were as follows: $10 \%$ of the cows had a lactation length less than $24 \mathrm{~d}(25 \mathrm{~d}), 25 \%$ of the cows had a lactation length of less than $124 \mathrm{~d}(87 \mathrm{~d}), 75 \%$ had a lactation length of less than $385 \mathrm{~d}(374 \mathrm{~d})$, and $90 \%$ had a lactation length of less than $424 \mathrm{~d}$ (408 d). Only $2.5 \%$ had a lactation length over $457 \mathrm{~d}$. Lactations were censored in later analyses at $457 \mathrm{~d}$ to avoid extreme values and any later CM events were excluded from further analyses.

A total of 10,821 lactations were included, but housing information was missing from 812 lactations, which left a total of 10,009 lactations. A total of 1,005 (924) CM cases from $4,557(5,452)$ lactations were recorded in the lactations before (during) the trial. In total, 3,750 $(4,719)$ cows had 1 lactation, 798 (726) cows had 2, and 9 (7) cows had 3 lactations. Altogether, $784(84.8 \%)$ of the recorded CM during the trial had a bacteriological milk sample. Staphylococcus aureus were isolated from $47.4 \%$, Strep. dysgalactiae from $22.5 \%, E$. coli from $10.7 \%$, CNS from $6.3 \%$. In addition, $12.5 \%$ were bacteriologically negative, and the remainder of the CM cases was caused by other microbes. 
The dry-cow therapy distribution at herd (\% of cows) level was 62 herds (32.4\%) in the Juvanesta group, 60 $(35.2 \%)$ in the Siccalactin group, and $56(32.4 \%)$ in the Mastipen group. A total of 768 cows received selective dry-cow therapy during the trial: 231 cows were treated in the Juvanesta group, 322 cows in the Siccalactin group, and 215 cows in the Mastipen group. The teatdipping distribution at herd (\% of cows) level was as follows: $71(43.3 \%)$ herds in the teat-dip group A (negative), $52(27.6 \%)$ in group B (iodine), and $55(29.2 \%)$ in group C (external teat sealant).

There were $8,229(76.1 \%)$ lactations from cows housed in tie-stalls before and during the trial. Of the 4,456 lactations during the trial, 1,703 lactations received no dipping (group A), 1,375 lactations received iodine dipping (group B), and 1,378 lactations received an external teat sealant (group C). There were 1,780 lactations from cows (16.5\%) housed in free-stalls before and during the trial. Of the 996 lactations during the trial, 619 lactations received no dipping during the trial, 178 lactations received iodine dipping, and 199 lactations received an external teat sealant. Staphylococcus aureus were isolated from $48.5 \%$ (41.9\%) of the cows with CM in tie-stalls (free-stalls), Strep. dysgalactiae from $22.7 \%$ (21.8\%), E. coli from 9.9\% (14.4\%), and CNS from $7.0 \%(3.2 \%)$. There were no significant differences in bacteriology between cows housed in tie-stalls and free-stalls.

\section{Description of the Control Herds}

For the 602 control herds, the herd characteristics during the trial were as follows: the mean herd size was 24 cows $(\mathrm{SD}=10.9)$, the mean annual milk yield was $6,427 \mathrm{~kg}(\mathrm{SD}=911)$, and the mean bulk milk SCC was 113,000 cell $\mathrm{s} / \mathrm{mL}(\mathrm{SD}=38,000)$. The distribution of parities and length of lactation was not significantly different from the participating herds.

Included in the models were a total of 31,951 lactations: 15,328 lactations before and 16,623 during the trial. There were 12,656 (14,380 during) cows that had 1 lactation, 2,649 (2,220 during) cows had 2, and 23 (23 during) cows had 3 lactations. Treated CM cases were recorded before and during the trial. A total of 2,762 $(2,664) \mathrm{CM}$ cases were recorded in the lactations before (during) the trial.

\section{Statistical Models}

Participating Herds. The interactions between the dry-cow therapy groups (Juvanesta, Siccalactin, and Mastipen) and the lactation belonging to the period before and during the trial were omitted from the full model because these variables did not contribute sig- nificantly. In the final models, parity (class $1,2,3$ and $>3$ ), teat-dipping groups A vs. B and C, lactation before or during the trial, and the interaction between teatdipping group $\mathrm{B}$ (iodine) vs. A and $\mathrm{C}$ and lactation before and during the trial were used as independent variables. Table 1 shows that the risk of CM was significantly $(P<0.05)$ decreased by $13 \%$ (HR $=0.87 ; 95 \%$ CI: $0.77-0.98)$ in tie-stalls when comparing lactations during with lactations before the trial. The same trend was seen in free-stalls (HR $=0.82$; 95\%, CI: $0.65-1.04$; Table 2), although it was not significant. In tie-stalls, there were no significant associations between the risk of CM before or during the trial, or between the teatdipping groups $\mathrm{A}$ (control) and $\mathrm{C}$ (external teat sealant). Because the significant difference only existed between the iodine group (B) and the 2 other groups (A and C), the 2 other groups were used as a combined reference group in the model (Table 1). The survival distribution function of CM events according to DIM before and during the trial for the iodine group (B), compared with the combined group (A and C) is illustrated in Figure 1 for tie-stalls and Figure 2 for free-stalls. The freestall herds in teat-dip group B had a significantly lower risk of achieving CM both before and during the trial, compared with the external teat sealant and no-dipping herds (C and A). Lactation number was significantly associated with HR of CM in both type of herds and cows with parity $>3$ having the highest risk both in tie-stalls $(\mathrm{HR}=1.68$; Table 1$)$ and free-stalls $(\mathrm{HR}=$ 2.18; Table 2).

The separate model made for the association of Staph. aureus CM during the trial showed no significant association between type of housing, season, and dry-cow therapy. The only significant variables for Staph. aureus $\mathrm{CM}$ were parity 3 with an $\mathrm{HR}=1.5$ (CI: $1.1-$ 1.9), parity $>3$ with an HR = 1.4 (CI: $1.1-1.8$ ) compared with parities $<3$, and external teat sealant with an $\mathrm{HR}=1.2$ (CI: 1.0-1.5) compared with control and iodine teat dipped cows. The separate models made for the other CM pathogens (Strep. dysgalactiae, E. coli, and CNS) showed no significant association between the pathogens and type of barn, teat-dipping treatment, and dry-cow therapy. The only significant variables were parity 3 and parity $>3$.

Control Herds. The final model, which included the control herds, showed a general significant reduction in $\mathrm{CM}$ for the control herds during the trial period, with a decreased HR of 0.95 (CI: 0.90-1.00) compared with the lactations before the trial period. The difference before and during the trial period for these control herds allocated to be in the iodine group (B), as well as for the combined group (A and C) is graphically illustrated in Figure 3. The participating herds started with an 
Table 1. Risk factors for clinical mastitis in Norwegian Red cattle in tie-stalls, before and during the trial, using Cox survival analysis model ( $\mathrm{n}=8,229$ lactations, 6,629 lactations were censored, and 1,597 lactations featured an episode of clinical mastitis)

\begin{tabular}{|c|c|c|c|c|c|c|c|}
\hline Independent variables & Class & $\begin{array}{l}\text { Lactations, } \\
\mathrm{n}\end{array}$ & Estimate & $\mathrm{SE}$ & $P$-value & $\mathrm{HR}^{1}$ & $\begin{array}{l}95 \% \mathrm{CI}^{2} \\
\mathrm{HR}\end{array}$ \\
\hline \multirow[t]{2}{*}{ Lactations $^{3}$} & Lactations before the trial $=0$ & 3,773 & 0 & 0 & - & 1.00 & - \\
\hline & Lactations during the trial $=1$ & 4,456 & -0.14 & 0.06 & $<0.05$ & 0.87 & $0.77-0.98$ \\
\hline groups before the trial & Iodine & 1,206 & 0.21 & 0.12 & 0.07 & 1.23 & $0.98-1.56$ \\
\hline \multirow{2}{*}{$\begin{array}{l}\text { Allocated to different teat-dip } \\
\text { groups during the trial } \\
\text { Parity }\end{array}$} & Neg con/ETS & 3,081 & 0 & 0 & - & 1.00 & - \\
\hline & Iodine & 1,375 & -0.23 & 0.11 & $<0.05$ & 0.79 & $0.64-0.99$ \\
\hline & $>3$ & 1,487 & 0.52 & 0.07 & $<0.01$ & 1.68 & $1.47-1.93$ \\
\hline Dependent parameter (Theta) & Herd & 142 herds & 0.85 & 0.02 & $<0.01$ & & \\
\hline
\end{tabular}

${ }^{1} \mathrm{HR}=$ Hazard ratio.

${ }^{2} \mathrm{CI}=$ Confidence interval.

${ }^{3}$ Comparing lactations before and during the trial.

${ }^{4} \mathrm{Neg}$ con/ETS = Negative control/external teat sealant.

HR of 1.25 (CI: 1.16-1.34) compared with the nonparticipating herds, and the herds included in the trial had a reduction of $\mathrm{CM}$ during the trial corresponding to an $\mathrm{HR}=0.85$ (CI: 0.78-0.95) during the trial compared with before the trial.

\section{DISCUSSION}

The overall CM reduction was only 5\% in the control herds located in the same geographical area as the trial. The results of the control herds illustrated that $\mathrm{CM}$ reduction during the trial could not be attributed to a general trend within the population. There is a possibility that some of the $\mathrm{CM}$ reduction of $5 \%$ in the control herds could be attributed to the fact that some veterinarians and farmers learned from the trial or from their neighbors and applied the principles of the trial to the control herds. To identify a true change of the CM risk in the participating herds, it is important to compare with the herd status before the trial as well as changes during the same time span for nonparticipating herds. Epidemiologically, this is done by using the interaction term between the period (before vs. during the trial period) and the category of herd (control vs. participating herd). This interaction was significant in our study. The additional reduction of $15 \%$ in CM in the participating herds is most probably attributed to changes in management: selective dry-cow therapy and culling of chronically infected cows (cows with geometric mean on 3 test-days of CMSCC $>700,000$ cells $/ \mathrm{mL}$ ). The trial herds had an HR of 1.25 higher than the control herds before the trial. This could be due to the selection process whereby we wanted to include herds with a lot of Staph. aureus isolates. It is well known that herds with

Table 2. Risk factors for clinical mastitis in Norwegian Red cattle, housed in freestalls, before and during the trial, using Cox survival analysis model ( $\mathrm{n}=1,780$ lactations, 1,454 lactations were censored, and 325 lactations featured an episode of clinical mastitis).

\begin{tabular}{|c|c|c|c|c|c|c|c|}
\hline Independent variable & Class & $\begin{array}{l}\text { Lactations, } \\
\mathrm{n}\end{array}$ & Estimate & $\mathrm{SE}$ & $P$-value & $\mathrm{HR}^{1}$ & $\begin{array}{l}95 \% \mathrm{CI}^{2} \\
\mathrm{HR}\end{array}$ \\
\hline \multirow[t]{2}{*}{ Lactations $^{3}$} & Lactations before the trial $=0$ & 784 & 0 & 0 & - & 1.00 & - \\
\hline & Lactations during the trial $=1$ & 996 & -0.20 & 0.12 & 0.09 & 0.82 & $0.65-1.04$ \\
\hline groups before the trial & Iodine & 155 & -1.42 & 0.43 & $<0.001$ & 0.24 & $0.10-0.56$ \\
\hline Allocated to different teat-dip & Neg con/ETS & 818 & 0 & 0 & - & 1.00 & - \\
\hline \multirow{2}{*}{$\begin{array}{l}\text { groups during the trial } \\
\text { Parity }\end{array}$} & Iodine & 178 & -0.18 & 0.42 & NS & 0.84 & $0.37-1.90$ \\
\hline & $>3$ & 328 & 0.78 & 0.16 & $<0.01$ & 2.18 & $1.59-2.99$ \\
\hline Dependent parameter (Theta) & Herd & 22 herds & 0.90 & 0.05 & $<0.05$ & & \\
\hline
\end{tabular}

${ }^{1} \mathrm{HR}=$ Hazard ratio.

${ }^{2} \mathrm{CI}=$ Confidence interval.

${ }^{3}$ Comparing lactations before and during the trial.

${ }^{4} \mathrm{Neg}$ con/ETS = Negative control/external teat sealant. 

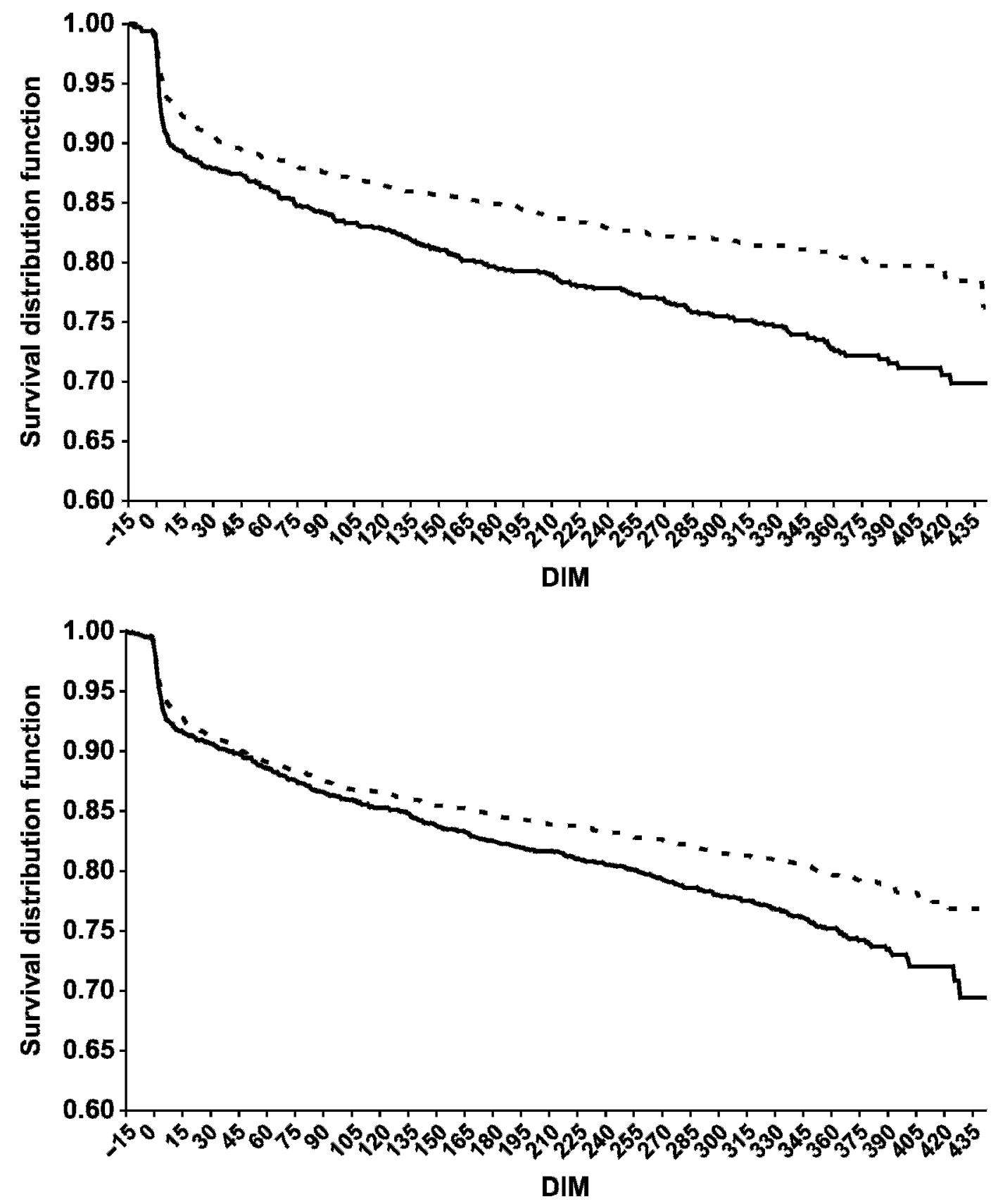

Figure 1. Survival distribution function for treatment of clinical mastitis in tie-stalls, before (-) and during (- - -) the trial in (top panel) herds teat-dipped with iodine (teat-dip group B), and (bottom panel) the combined negative control (no dip) and external teat sealant group (groups A and C).

a high CM rate will tend to move toward the mean; however, the rate of $1,005 \mathrm{CM}$ cases in 4,557 lactations $(0.22)$ is already close to the country mean of 0.22 (Østerås, 2003), whereas $2,762 \mathrm{CM}$ cases in 15,328 lactations in the control herds $(0.18)$ is further from the country mean. Due to the probable carryover effect to neighboring herds, the general $\mathrm{CM}$ reduction in the trial of $15 \%$ is probably an underestimated association rather than an overestimation.

Selective dry-cow therapy combined with iodine teat dipping decreased the HR of CM by $21 \%$, compared with no dipping or an external teat sealant in tie-stalls. The same trend (a 16\% reduction) was seen in the freestalls, although it was not significant. There were fewer 

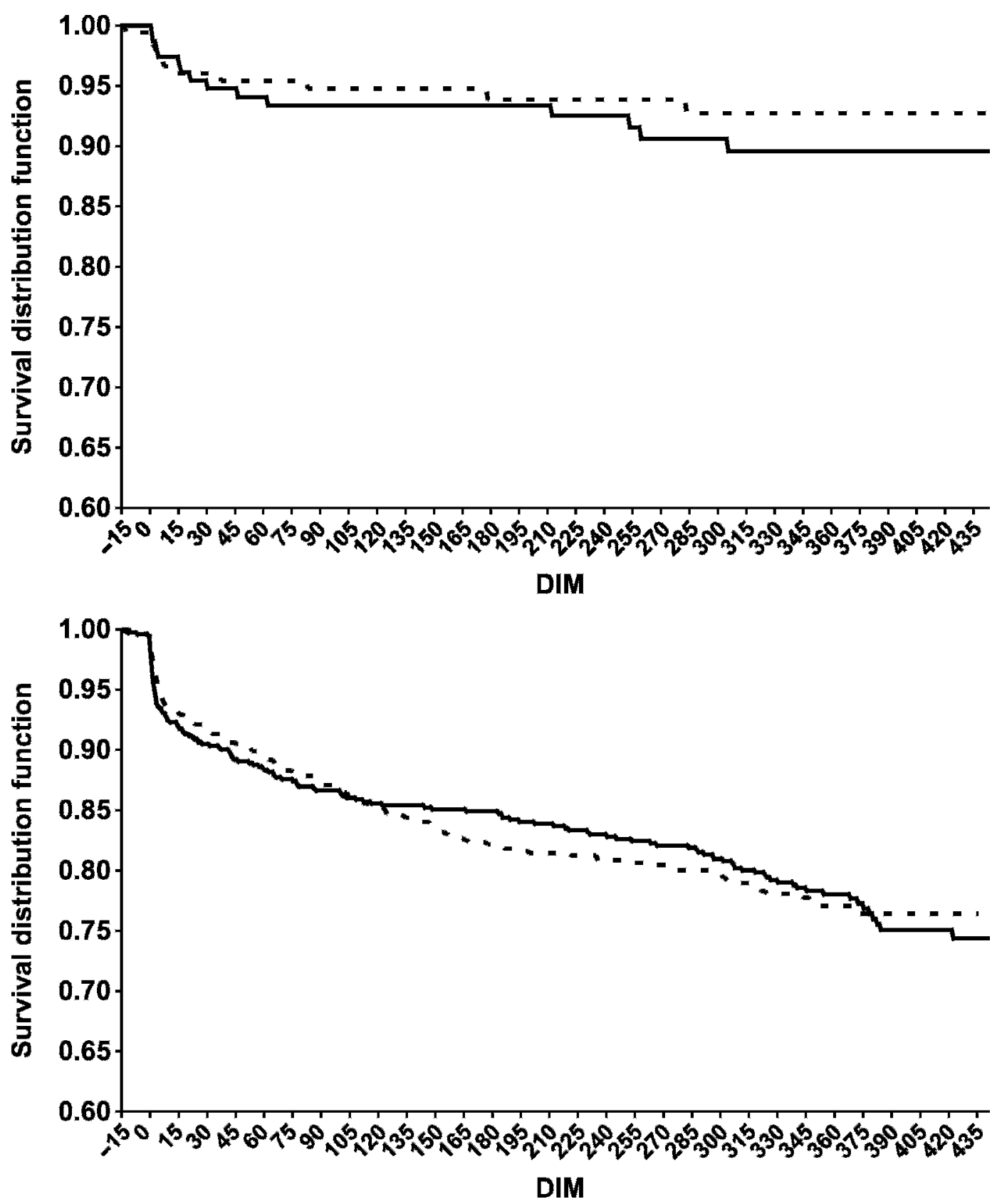

Figure 2. Survival distribution function for treatment of clinical mastitis in free-stalls, before (-) and during (- - -) the trial in (top panel) herds teat-dipped with iodine (teat-dip group B), and (bottom panel) the combined negative control (no dip) and external teat sealant group (groups A and C).

free-stall herds and hence, less statistical power, which could be the reason for the nonsignificant result (compare Figures 1, 2, and 3).

In the present study, there was no significant association between the different types of selective dry-cow therapy and HR of CM. This was expected because only 768 out of 5,452 completed lactations (14\%) received dry-cow therapy. Additionally, approximately $39 \%$ of these lactations were in first-parity cows, which could not have received any dry-cow therapy before their first calving, leaving $23 \%$ of older cows to have had a drycow therapy. Doing CM research throughout different lactations within the complete herd, also for those $86 \%$ that did not receive any dry-cow therapy, we did not expect to reveal any significant association between the 3 different treatments and CM. Although we did not 

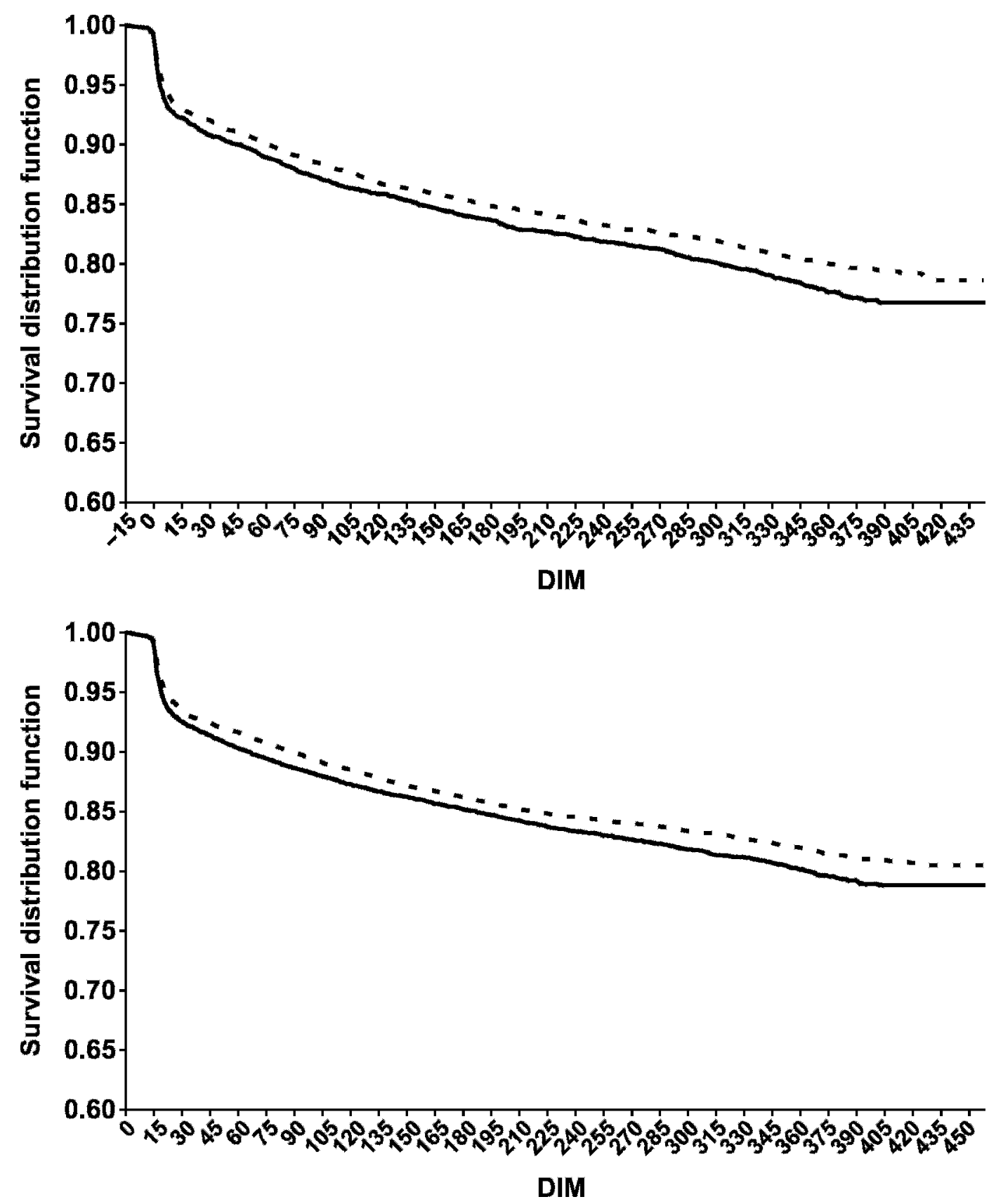

Figure 3. Survival distribution function for treatment of clinical mastitis in control herds (not in the project), before (-) and during (- - -) the trial period in (top panel) herds pre-planned and randomized to the group teat-dipped with iodine (teat-dip group B), and (bottom panel) pre-planned and randomized to the combined negative control (no dip) and external teat sealant group (groups A and C).

expect such an association, it would be scientifically correct to control if there was any effect. Further research is needed to look at differences in contracting $\mathrm{CM}$ among among cows treated with dry-cow therapy only.

The trial used teat dipping, negative control or an external teat sealant, at herd level, over a 2-yr period in 164 commercial dairy herds. The farmers were encouraged to follow the protocol, but there will always be individual differences in large field trials, which will reflect typical commercial use of the products. Complete lactations within the trial were followed from one calving until the next calving or culling. Thus, any effect of an earlier teat-dipping regimen should be avoided because of the time interval (at least days, but usually months) between calving and being introduced into the study. Our findings are in agreement with the conclu- 
sions from 4 natural-exposure iodine trials with a negative control (Eberhart et al., 1983; Nickerson et al., 1986; Oliver et al., 1991). However, it is difficult to compare our results with these trials because none of them were conducted at the herd level, none of them were large field trials in which commercial dairy herds used an iodine teat-dipping product for over a year, and none compared the CM risk before and during the trial. Eberhart et al. (1983) used one research herd with a history of various regimens of teat dipping and dry-cow treatment, free of Streptococcus agalactiae and a low prevalence of Staph. aureus. They used a split udder design and concluded that teat dip significantly reduced new IMI caused by Staph. aureus (1 case vs. 6 cases) and Streptococcus spp. (3 cases vs. 12 cases). Nickerson et al. (1986) used 2 postmilking teat dips containing 0.5 and $1 \%$ iodine for 8 mo in 4 commercial dairy farms, in a split herd design. In 1 of the herds, 8 quarters were infected with Staph. aureus compared with 3 quarters in the negative control group, but in total (from all 4 herds), there were 14 IMI caused by Staph. aureusinfected quarters in the dipping groups, and 43 IMI in the negative control group. Oliver et al. (1991) described 2 natural-exposure herd studies, one research herd with a high prevalence of contagious mastitis pathogens, and one research herd with a high prevalence of environmental mastitis pathogens, to evaluate the effect of $0.25 \%$ available iodine. Both studies used a split herd design with a negative control group. They concluded that there was a significant reduction of new IMI caused by Staph. aureus, Strep. agalactiae and other Streptococcus spp. in the first study, but not in the second study. Because the studies mentioned above were performed in only a few herds, any extrapolation to other herds should be done with care. The significant large herd cluster effect of CM, as demonstrated in our study, also indicates such caution of extrapolating from studies including only a few herds.

If tie-stalls and free-stalls are put together in the same model, iodine dipping was not associated significantly with reducing the CM risk. Free-stalls are a confounder in this study and have to be included in the model (Figure 2). The demonstrated association between the HR of CM and iodine dipping would be missing if the data set were not differentiated between tiestalls and free-stalls. Iodine teat dipping was used in only 4 free-stall herds during the trial and these herds had a significantly lower CM risk before they were included into the trial compared with the other teat-dipping groups stalled in free-stalls. It is possible that iodine teat dipping has an association with reduced CM risk in free-stalls as well, but the data set in this trial is too small, and the power too weak to reveal significant differences.
There are few published papers on the effect of an external teat sealant conducted in a natural-exposure field trial. The use of an external teat sealant showed no benefit in this trial. Trials in which external teat sealant has been applied 7 to $10 \mathrm{~d}$ before expected calving have shown an effect on CM caused by environmental pathogens (Timms, 2001). The reason why our results were not in agreement could be that most of the $\mathrm{CM}$ cases in this trial took place postpartum and were caused by Staph. aureus and Strep. dysgalactiae.

There were no significant associations among pathogen-specific CM cases caused by Staph. aureus, Strep. dysgalactiae, E. coli, CNS and housing facilities, different dry-cow therapy treatments, and season. Parity 3 and parity $>3$ were the only variables that contributed significantly except for Staph. aureus mastitis, in which an external teat sealant was associated with more Staph. aureus mastitis compared with iodine dip and control groups. There was a trend, although not significant, for more E. coli mastitis and fewer Staph. aureus $\mathrm{CM}$ to occur in free-stalls compared with tie-stalls.

The significant cluster effect observed between the herds is expected. A CM treatment decision within a herd is primarily a decision made by the farmer based on subjective motives influenced by several economic variables. To account for this effect, we used the macro of Shu and Klein (2005) to adjust for the frailty effect at herd level. The results confirmed a very significant frailty effect.

It is important to know the risk of $\mathrm{CM}$ in the herds before implementing a dry-cow therapy or teat-dipping protocol; otherwise, it is impossible to measure a decrease or an increase. The risk of CM varies in different countries and in individual herds. In the Nordic countries, cases of CM are usually treated and recorded by veterinarians, and can therefore be obtained from the national health control register. The high incidence of culling due to mastitis would cause selection bias and can generate problems in epidemiology studies. Cox modeling is suitable for managing such data, where cows have different observation time. A culling event and a CM case mark the end of the observation period in Cox models and are therefore preferred to logistic regression.

It is also important to have control herds when running trials to see if the same results, as claimed by the trial, are not occurring in the general population and are in the nontrial herds. In this study, a $15 \%$ reduction in the HR of CM could be attributed to the trial performed in 164 participating herds compared with 602 control herds within the same geographic area.

\section{CONCLUSIONS}

Implementation of selective dry-cow therapy and culling of high CMSCC cows was associated with a gen- 
eral decrease of CM risk by $15 \%$, whereas the general decrease in CM risk in the control herds in the same period was only $5 \%$. Comparing tie-stall, iodine-dipped herds before and after the trial, there was a significant (21\%) decrease in CM risk. These herds started at a higher CM level and ended up with $2.5 \%$ less CM than the nondipped or external teat sealant herds. The same trend was seen in free stalls. Older cows (parity > 3) had the highest $\mathrm{HR}$ of contracting $\mathrm{CM}$ in both tie-stalls (1.66) and free-stalls (2.13).

\section{ACKNOWLEDGMENTS}

The authors would like to thank all the participating farmers, veterinarians, and laboratory workers for their involvement in the research. We would also like to thank Boehringer-Ingelheim, VetPharma, and DeLaval for their contributions of intramammary therapies and teat dips. Access to the data was given by the Norwegian DHRS and the Norwegian Cattle Health Services (for health data) in agreement number 8/2002. The study was financially supported by grants from the Research Council of Norway.

\section{REFERENCES}

Alfnes, T., and O. Østerås. 1992. Milking and milking management. Landbruksforlaget, Oslo, Norway. [In Norwegian]

Allison, P. D. 2000. Survival Analysis using the SAS system. SAS Institute, Cary, NC.

Barkema, H. W., Y. H. Schukken, T. J. G. M. Lam, M. L. Beiboer, G. Benedictus, and A. Brand. 1999a. Management practices associated with the incidence rate of clinical mastitis. J. Dairy Sci. 82:1643-1654

Barkema, H. W., J. D. van der Ploeg, Y. H. Schukken, T. J. G. M. Lam, G. Benedictus, and A. Brand. 1999b. Management style and its association with bulk milk somatic cell count and incidence rate of clinical mastitis. J. Dairy Sci. 82:1655-1663.

Bratlie, O. 1972. Dry cow therapy. Nord. Vet. Med. 24:433-439.

Browning, J. W., G. A. Mein, M. Barton, T. J. Nicholls, and T. Brightling. 1990. Effects of antibiotic therapy at drying off on mastitis in the dry period and early lactation. Aust. Vet. J. 67:440-442.

Browning, J. W., G. A. Mein, T. Brightling, T. J. Nicholls, and M. Barton. 1994. Strategies for mastitis control: Dry cow therapy and culling. Aust. Vet. J. 71:179-181.

Cox, D. R. 1972. Regression models and life-tables (with discussion). J. Royal Stat. Soc. B 34:187-220.

Eberhart, R. J., P. L. LeVan, L. C. Griel, and E. M. Kesler. 1983. Germicidal teat dip in a herd with low prevalence of Streptococcus agalactiae and Staphylococcus aureus mastitis. J. Dairy Sci. 66:1390-1395.

International Dairy Federation (IDF). 1981. Laboratory methods for use in mastitis work. Bull. no. 132. IDF, Brussels, Belgium.
International Dairy Federation (IDF). 1999. Suggested interpretation of mastitis terminology. Bull. no. 338. IDF, Brussels, Belgium.

Kingwill, R. G., F. K. Neave, F. H. Dodd, T. K. Griffin, and D. R. Westgarth. 1970. The effect of a mastitis control system on levels of subclinical and clinical mastitis in two years. Vet. Rec. 87:94-100.

National Veterinary Institute. 1993. Laboratory routines for mastitis diagnostics at the State Veterinary Laboratories. Oslo, Norway. [In Norwegian]

Nickerson, S. C., J. L. Watts, R. L. Boddie, and J. W. Pankey. 1986. Evaluation of $0.5 \%$ and $1 \%$ iodophor teat dips on commercial dairies. J. Dairy Sci. 69:1693-1698.

Oliver, J., F. H. Dodd, and F. K. Neave. 1956. Infection and mastitis in a dairy herd 1945-53. J. Dairy Res. 23:169-180.

Oliver, S. P., M. J. Lewis, S. H. King, B. E. Gillespie, T. Ingle, K. R. Matthews, H. H. Dowlen, P. A. Drechsler, E. E. Wildman, and J. W. Pankey. 1991. Efficacy of a low concentration iodine postmilking teat disinfectant against contagious and environmental mastitis pathogens in two dairy herds. J. Food Prot. 54:737-742.

Østerås, O. 2003. Cattle health card records 2002. Norsk Veterinærtidsskrift. 115:431-442.

Østerås, O., V. L. Edge, and S. W. Martin. 1999. Determinants of success or failure in the elimination of major mastitis pathogens in selective dry cow therapy. J. Dairy Sci. 82:1221-1231.

Østerås, O., and A. Lund. 1988a. Epidemiological analyses of associations between udder health and housing. Prev. Vet. Med. 6:79-90.

Østerås, O., and A. Lund. 1988b. Epidemiological analyses of associations between udder health and milking machine and milking management. Prev. Vet. Med. 6:91-108.

Østerås, O., and L. Sandvik. 1996. Effects of selective dry-cow therapy on culling rate, clinical mastitis, milk yield and cow somatic cell count. A randomized clinical field study in cows. J. Vet. Med. B. 43:555-575.

Østerås, O., and L. Sølverød. 2005. Mastitis control systems: The Norwegian experience. Pages 91-101 in Proc. 4th Int. Mastitis Seminar. Wageningen Academic Publishers, Wageningen, the Netherlands.

Østerås, O., L. Sølverød, and O. Reksen. 2006. Milk culture results in a large Norwegian survey-Effect of season, parity, days in milk, resistance and clustering. J. Dairy Sci. 89:1010-1023.

Schukken, Y. H., J. Buurman, A. Brand, D. VandeGeer, and F. J. Grommers. 1990. Population dynamics of bulk milk somatic cell counts. J. Dairy Sci. 73:1343-1350.

Shu, Y., and J. P. Klein. 1999. A SAS macro for the positive frailty model. Page 47-52 in Proc. Am. Stat. Assoc.: Statistical Computing section. Am. Stat. Assoc., Alexandria, VA.

Shu, Y., and J. P. Klein. 2005. A SAS Macro for the positive stable frailty model. Available: http://www.biostat.mcw.edu/software/ SoftMenu.html Accessed Sep. 21, 2006.

Solbu, H. 1983. Disease recording in Norwegian dairy cattle. I. Disease incidences and non-genetic effects on mastitis, ketosis and milk fever. Z. Tierz. Zuchtungsbio. 100:139-157.

Timms, L. L. 2001. Field trial evaluation of a novel persistent barrier teat dip for preventing mastitis during the dry period and as a potential substitute for dry cow antibiotic therapy. Page 262-263 in Proc. NMC Annu. Mtg., Reno, NV. National Mastitis Council, Verona, WI.

Whist, A. C., O. Østerås, and L. Sølverød. 2006. Staphylococcus aureus and Streptococcus dysgalactiae in Norwegian herds after introduction of selective dry cow therapy and teat dipping. J. Dairy Res. doi:10.1017/s0022029906002135 